(C) 2018

Войтенко С. Л., доктор сільськогосподарських наук

Полтавська державна аграрна академія

\title{
ВПЛИВ ІНБРИДИНГУ РІЗНИХ СТУПЕНІВ НА ЖИВУ МАСУ СВИНОК ТА ЇХ ВЛАСНУ ПРОДУКТИВНІСТЬ
}

\section{Рецензент - доктор сільськогосподарських наук А. А. Поліщук}

У статті висвітлена проблема інбридингу у свинарстві, зокрема під час розведення свиней нечисленної, локальної породи. Встановлений позитивний вплив інбридингу на живу масу свинок у процесі їх вирощування. Найбільш високу жсиу масу за відлучення у 45-денному віці мали свинки із найменшим коефіиієнтом інбридингу (0,78-1,56\%), але в процесі росту тварин, особливо із 6-місячного віку, тенденція змінюеться $i$ найбільшу живу масу мали свинки із більш високим коефіиієнтом інбридингу (6,2411,7\%). Позитивні наслідки інбридингу помірних $i$ віддалених ступенів відмічені $i$ за показниками власної продуктивності свинок. Доведено, щзо із підвищенням коефіuієнту інбридингу з 1,56\% до 11,7\% вік досягнення тваринами живої маси 100 кг зменшувався на 11,4 днів $(P>0,95)$, а товщчина шпику, виміряна прижиттево, - на 2,7 мм. На підставі чого зроблений узагальнюючий висновок про можливість спорідненого підбору батьківських пар у миргородській породі свиней з метою одержання потомків, комплексний коефіиієнт інбридингу яких не вище 11,7\%.

Ключові слова: споріднене розведення, інбридинг, коефіцієнт інбридингу, свинки, миргородська порода, жива маса, власна продуктивHicmb.

Постановка проблеми. В практиці тваринництва загальновизнаними $є$ три методи розведення: чистопородне розведення, схрещування і гібридизація. Не акцентуючи уваги на їх призначенні, хотілося б сказати, що без чистопородного розведення, коли для парування підбирають тварин однієї породи, інші методи були б не ефективними. Загальновизнано, що лише чистопородні тварини здатні передавати своїм потомкам цінні ознаки продуктивності за їх консолідації у поколіннях.

Розведення чистопородних тварин завжди було складним елементом не лише для свинарства, але й взагалі тваринництва. Якщо породу чи популяцію довго розводити «в чистоті», тварини стають генетично подібними, консолідованими, але при цьому знижується мінливість ознак і стає проблематично отримати внутрішньопородний гетерозис. За великого поголів'я тварин чистопородне розведення в породі можна підтримувати за рахунок гетерогенного підбору бать- ківських пар, міжлінійних кросів і «освіжіння крові», тобто неспорідненого розведення. Якщо ж порода знаходиться на етапі створення чи навпаки, втрачає своє значення у галузі та переміщається у категорію зникаючих порід, застосовують інший метод чистопородного розведення - інбридинг, або парування тварин, які споріднені між собою.

На думку науковців, споріднене розведення, якщо його застосовувати не постійно і не стихійно, не приводить до негативних наслідків, в числі яких зниження життєздатності, інтенсивності росту, плодючості тощо [2, 4, 6, 8]. I навіть якщо не можна уникнути систематичного його використання, слід враховувати ступінь інбридингу, не допускаючи кровозмішування чи тісного інбридингу [3, 9].

Миргородська порода свиней на даному етапі знаходиться в категорії локальних нечисленних вітчизняних порід, яка розводиться лише в одному племінному господарстві і не може уникнути спорідненого розведення. Саме тому значний інтерес викликає вплив різних ступенів інбридингу на показники продуктивності свиней, особливо зміну їх живої маси в динаміці вирощування.

Аналіз останніх досліджень і публікацій, у яких започатковано розв'язання проблеми. За переконанням багатьох дослідників, інбридинг, або споріднене розведення тварин, є найбільш надійним методом збереження або підсилення цінних ознак, характерних для стада чи породи. Зрозуміло, що чим подібніші між собою батьки і аналогічніші умови зовнішнього середовища в низці поколінь, тим вищою буде успадковуваність ознак у потомків $[1,5,8,11]$. Проте корифеї зоотехнічної науки вважають, що споріднене розведення рано чи пізно приведе до зниження пристосованості тварин до умов їх утримання, життєздатності, продуктивності тощо [2, $8,11]$. Особливо негативні наслідки інбридингу у свинарстві $[5,7,9,13]$, у зв'язку з чим застосування спорідненого розведення свиней у межах чотирьох поколінь категорично заборонено. Як виключення - створення нових селекційних до- 


\section{СІЛЬСЬКЕ ГОСПОДАРСТВО. ТВАРИННИЦТВО}

сягнень. 3 чого можна зробити висновок, що не сам по собі інбридинг шкідливий чи корисний, а має значення ступінь інбридингу, тобто в якому ряду родоводу знаходяться спільні предки пробанда, а також як часто він застосовується. Саме тому застосування методу інбридингу під час розведення тварин повинно супроводжуватися постійним контролем ознак, які є предметом селекції.

Аналізуючи сучасне свинарство та кількість імпортованих тварин у більшості із наявних в Україні порід, можна зробити висновок, що проблема інбридингу не актуальна, крім нечисельних локальних порід. Так, саме збереження генофонду місцевих вітчизняних порід свиней за їх чистопородного розведення виводить на перше місце проблему інбридингу, оскільки зменшення їх поголів'я неминуче призведе до спарування плідників і маток, які мають спільних предків у родоводах. Запропоновані для великої рогатої худоби схеми ротацій для подолання інбридингу в цих популяціях не дієві, оскільки немає кріоконсервованої сперми плідників, а методичні підходи до розведення свиней дещо інші, порівняно зі скотарством. Не додало оптимізму і впровадження для нечисельних порід, серед яких миргородська, українська степова біла та українська степова ряба, методу штучного осіменіння.

3 урахуванням цього залишається лише спостерігати та аналізувати генетичну ситуацію в породах за використання спорідненого розведення, а також визначати найбільш вдалі варіанти підбору батьківських пар, які не призводять до прояву інбредної депресії у потомків.

Враховуючи, що споріднене розведення найбільш часто проявляється за життєздатністю тварин та інтенсивністю їх росту, нами була вивчена жива маса свиноматок миргородської породи в динаміці їх вирощування, а також проведена оцінка тварин за їх власною продуктивністю у залежності від їх інбредності (коефіцієнту інбридингу).

Мета досліджень - визначити живу масу свиноматок миргородської породи у залежності від коефіцієнту інбридингу (гомозиготності) та зробити висновок про можливість спорідненого розведення різних ступенів у локальній популяціï.

Завдання досліджень - визначити наявність інбредних свиноматок у миргородській породі та встановити зв'язок їх живої маси із коефіцієнтом інбридингу (гомозиготності).

Матеріал і методи досліджень. Дослідження проведені на свиноматках миргородської поро- ди, які належали до 11 генеалогічних родин. Визначення коефіцієнта інбридингу (гомозиготності) проводили за родоводом тварини, поданим у картці племінної свиноматки та використання загальновідомої формули Райта-Кисловського [8]. Враховуючи, що свині миргородської породи давно розводяться закритою популяцією в межах одного стада і в родоводах частини 3 них декілька інбредних предків, нами був розрахований комплексний коефіцієнт інбридинг як сума усіх розрахованих коефіцієнтів інбридингу по кожній тварині. Для визначення впливу спорідненого розведення на живу масу свиноматок вони були згруповані в залежності від коефіцієнту інбридингу: I група - коефіцієнт інбридингу 0,78-1,56 \%; II група - 2,34-4,68 \% та III група 6,24-11,7\%. Оцінку свинок проводили за їх живою масою в разі відлучення в 45 днів, в 4 місяці, 6 місяців, 9 місяців, а також показниками їх власної продуктивності, визначеної під час вирощування (вік досягнення живої маси 100 кг та товщиною шпику на рівні 6-7-го грудних хребців). Визначення досліджуваних показників проводили за загальновідомими методиками у свинарстві. Достовірність досліджуваних показників між групами маток визначали за порівняння до першої групи. Рівень годівлі та технологія утримання тварин забезпечували прояв їх генетичного потенціалу.

Результати досліджень. Дослідженнями встановлено, що свинки миргородської породи різного ступеня інбридингу в процесі росту хоча й мали дещо різну живу масу, але ця різниця була не достовірною. Найбільш відчутно за відлучення вплив інбридингу проявився по живій масі свинок, де тварини I групи, коефіцієнт інбридингу яких знаходився в межах 0,78-1,56 \%, переважали представниці інших груп на 1,7 кг та 1,3 кг, відповідно (табл. 1). Безперечно, можна допустити, що на живу масу свинок за відлучення вплинуло поєднання батьківських пар, при чому чим батьки більш однорідні за генотипом, тим жива маса їх потомків за відлучення менша. В усякому випадку в наших дослідженнях із підвищенням коефіцієнту інбридингу жива маса свинок за відлучення зменшувалася. Але в даний віковий період росту поросят не варто недооцінювати роль матері, особливо якість їі молока, яке $є$ основним видом корму для тварин до 21денного віку і впливає на їх живу масу під час відлучення.

У подальші вікові періоди, коли свинки миргородської породи знаходилися в однакових умовах утримання та годівлі, вплив спорідненого розведення був різний. Так, у чотирьохмісяч- 


\section{СІЛЬСЬКЕ ГОСПОДАРСТВО. ТВАРИННИЦТВО}

ному віці свинки різного ступеня інбридингу мали практично однакову живу масу, тобто вплив спорідненого розведення на розвиток даної ознаки був відсутній. Але починаючи із 6-місячного віку, інбредні свинки починають різнитися за живою масою, причому чим вищий коефіцієнт інбридингу, тим жива маса тварин була вищою. Так, свинки I групи з коефіцієнтом інбридингу 0,78-1,56 \%, мали живу масу 73,8 кг, II групи з коефіцієнтом інбридингу 2,34-4,68 \% - 74,1 кг і III групи - 3 коефіцієнтом інбридингу 6,24-11,7\% - 75,8 кг. Різниця за живою масою між тваринами першої і другої та третьої груп в цей віковий період становила 0,3 і 2 кг за недостовірної різниці. В наступний віковий період різниця між живою масою тварин мала аналогічну тенденцію деякої переваги у особин з вищим коефіцієнтом інбридингу, але теж без достовірної різниці між групами.

За період вирощування інбредних свинок від відлучення до 9-місячного віку перевага за живою масою була у тварин II групи, коефіцієнтом інбридингу який знаходився в межах 2,344,68 \% за найменшого показнику в особин I групи 3 найнижчим коефіцієнтом інбридингу $(0,78-$ $1,56 \%$ ). Тобто, навіть за недостовірної різниці між групами, можна зробити висновок про побічний позитивний вплив інбридингу на живу масу свинок миргородської породи. Причому споріднене розведення було більш результативним за умови збільшення коефіцієнту інбридингу у свинок.

Оцінюючи інбредних свинок за показниками їх власної продуктивності, слід вказати, що інбридинг і в даному випадку приводить до позитивних наслідків, оскільки не лише скорочує вік досягнення живої маси 100 кг, але й приводить до зменшення товщини шпику на рівні 6-7-го грудних хребців, що $є$ бажаним у свинарстві. Встановлено, що із підвищенням коефіцієнту інбридингу $32,34 \%$ до $11,7 \%$ вік досягнення тваринами живої маси 100 кг зменшився на 11,4 днів (P > 0,95), а товщина шпику, виміряна прижиттєво, - на 2,7 мм. Свинки I групи на 4 дні пізніше досягали живої маси 100 кг, порівняно 3 тваринами II групи (коефіцієнт інбридингу яких 2,34-4,68) та мали більшу на 2,3 мм товщину шпику. Свинки II групи поступалися представницям третьої групи за вищевказаними показниками, відповідно, на 7,4 днів та 0,4 мм.

Висновок. У випадку чистопородного розведення свиней локальних порід, які знаходяться в категорії зникаючих, можливе застосування спорідненого розведення батьківських пар із метою одержання потомків, комплексний коефіцієнт інбридингу яких буде не вище $11,7 \%$.

Наявність у родоводах свинок миргородської породи декількох спільних предків за помірних та віддалених ступенів інбридингу позитивно впливає на живу масу тварин та їх власну продуктивність, причому чим коефіцієнт інбридингу вищий за 2,34 \%, тим зниження товщини шпику та скорочення віку досягнення живої маси 100 кг під час вирощування більш відчутні. Проте верхня межа коефіцієнту інбридингу при цьому не вище $11,7 \%$.

Кращі показники власної продуктивності мали свинки, коефіцієнт інбридингу в яких був найвищим в стаді і знаходився в межах 6,24-11,7 \%.

Вплив ступеня інбридингу на живу масу свинок у процесі їх вирощування в окремі вікові періоди хоча й мав позитивне спрямування, але достовірно не підтверджений.

Жива маса та показники власної продуктивності інбредних свиноматок

\begin{tabular}{|l|c|c|c|}
\hline \multicolumn{2}{|c|}{ Показники } & \multicolumn{3}{|c|}{ Піддослідні групи } \\
\cline { 2 - 4 } & $\begin{array}{c}\text { I група } \\
(0,78-1,56)\end{array}$ & $\begin{array}{c}\text { II група } \\
(2,34-4,68)\end{array}$ & $\begin{array}{c}\text { III група } \\
(6,24-11,7)\end{array}$ \\
\hline Жива маса, кг: & $12,1 \pm 0,68$ & $10,4 \pm 0,49$ & $10,8 \pm 0,69$ \\
\hline у 45 днів & $44,9 \pm 0,91$ & $44,0 \pm 0,40$ & $44,5 \pm 0,75$ \\
\hline у 4 міс. & $73,8 \pm 1,11$ & $74,1 \pm 0,84$ & $75,8 \pm 1,89$ \\
\hline у 6 міс. & $120,5 \pm 0,87$ & $121,7 \pm 0,72$ & $121,4 \pm 1,31$ \\
\hline у 9 міс. & 108,4 & 111,3 & 110,6 \\
\hline абсолютний приріст, кг & $233,9 \pm 2,51$ & $229,9 \pm 1,75$ & $222,5 \pm 3,86 *$ \\
\hline $\begin{array}{l}\text { вік досягнення живої маси 100 кг } \\
\text { під час вирощування, дн. }\end{array}$ & $32,9 \pm 1,30$ & $30,6 \pm 1,04$ & $30,2 \pm 0,66$ \\
\hline $\begin{array}{l}\text { товщина шпику на рівні 6-7 груд- } \\
\text { них хребців, мм (прижиттєво) }\end{array}$ &
\end{tabular}

Примітка: * $\mathrm{P}>0,95$ 


\section{БІБЛІОГРАФІЯ}

1. Близнюченко О. Г. Генетика спорідненості та інбридингу / О. Г. Близнюченко // Тваринництво України. - 1988. - №1. - С. 23-25.

2. Борисенко Е. Я. Разведение сельскохозяйственных животных / Е. Я. Борисенко. - М. : Колос, 1967. - $268 \mathrm{c}$.

3. Борисенко Е. Я. О природе гетерозиса и инбредной депрессии // Известия ТСХА. - 1967. - №4. - С. 6-8.

4. Войтенко С. Л. Эффективность применения инбридинга в закрытой популяции свиней// Зоотехния. - 2003. - №8. - С. 13-14.

5. Ерохин А. И. Инбридинг и селекция животных / А. И. Ерохин, А. П. Солдатов, А. И. Филатов. - М. : Агропромиздат, 1985. - 155 с.

6. Крилова Л. Ф. Репродуктивні якості свиноматок 3 урахуванням спорідненості / Л. Ф. Крилова, А. М. Маслюк // Аграрний вісник Причорномор'я. - Вип. 31. - Одеса, 2005. C. 29-30.

7. Кудрявцев П. Н. О бессистемном инбридинге в свиноводстве // Проблемы животноводс-

тва.-1936. - №6. - С. 26-30.

8. Красота В. Ф. Разведение сельскохозяйственных животных / В. Ф. Красота, В. Т. Лобанов, Т. Г. Джапаридзе. - М. : Агропромиздат. 1990. - $463 \mathrm{c}$.

9. Мавродин А.Д. Влияние умеренного инбридинга на мясные качества / А. Д. Мавродин // Бюллетень ВНИИРЕЖ. - 1979. - №4. - С. 22-24.

10. Марченко Г. Г. Биологические особенности разных степеней инбридинга // Пути интенсификации животноводства в Повожье. - Саратов, 1988. - С. 10-14.

11. Разведение сельскохозяйственных животных с основами частной зоотехнии и промышленного животноводства / [Дмитриев Н. Г., Жигачев А. И., Вилль А. В. и др.]. - Л. : Агропромиздат, $1989 .-511 \mathrm{c}$.

12. Семешкин Н. П. Развитие половой системы и многоплодия свинок при интербридинге / Н. П. Семешкин // Сборник научных трудов МВА, 1982. - Вип. 16. - С. 71-74. 